\section{HIIT, RESISTANCE TRAINING, AND RISK FACTORS IN ADOLESCENTS: A SYSTEMATIC REVIEW}

\author{
HIIT,TREINAMENTO RESISTIDO EFATORESDERISCO EMADOLESCENTES:UMAREVISÃOSISTEMÁTICA
}

HIIT, ENTRENAMIENTO RESISTIDO YFACTORESDERIESGOENADOLESCENTES:UNAREVISIÓNSISTEMÁTICA

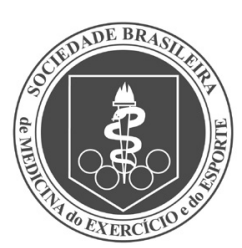

Systematic Review Article Artigo de ReVISÃo SISTEMÁtICA Artículo de ReVISIÓN SistemátICA
Waynne Ferreira de Faria' ${ }^{1}$ (Physical Education Professional) Filipe Rodrigues Mendonça' (ID) (Physical Education Professional) Rui Gonçalves Marques Elias' (ID) (Physical Education Professional) Raphael Gonçalves de Oliveira' (ID (Physical Education Professional) Antonio Stabelini Neto' (ID (Physical Education Professional)

1. Universidade Estadual do Norte do Paraná, Centro de Ciências da Saúde, Jacarezinho, PR, Brazil.

\section{Correspondence:}

Waynne Ferreira de Faria. Centro de Ciências da Saúde, Universidade Estadual do Norte do Paraná, Alameda Padre Magno, 841, Jacarezinho, PR, Brazil. 86400-000. waynne.faria@uenp.edu.br

\begin{abstract}
It has been shown that combined physical exercise is an efficient non-pharmacological approach in the context of public health, since it has demonstrated satisfactory results in the prevention, treatment and control of various morbidities. Therefore, it is essential to systematize current knowledge to enable professionals involved in the prescription of physical exercise to do so based on evidence. Thus, the objective of this study was to perform a systematic review of randomized clinical trials to verify changes in cardiometabolic risk factors induced by high-intensity interval training (HIIT) and resistance training (RT) in adolescents. The systematic search was performed in the following databases: Pubmed, ScienceDirect, Cochrane, LILACS and Scielo. Initially 933 studies were identified, then two researchers eliminated duplications and manuscripts that did not meet the eligibility criteria. Thus, two articles were included that met these criteria: a randomized clinical trial conducted with adolescents (10 to 19 years) of both sexes, an intervention lasting for at least four weeks, which prescribed HIIT and RT in the same session or not, and evaluation of at least one cardiometabolic risk factor. The results demonstrated that eight to 12 weeks of HIIT and RT without nutritional intervention were effective in significantly reducing waist circumference and body fat percentage. However, data pertinent to the efficacy of this combination on risk of developing type 2 diabetes mellitus and arterial hypertension are controversial. In view of the above, it is ascertained from the included studies that the combination of HIIT and RT has the potential to reduce cardiometabolic risk factors in adolescents; therefore, further studies should be conducted to determine the effectiveness of this prescription of physical exercise. Level of Evidence Il; Systematic review of Level II or Level I Studies with discrepant results.
\end{abstract}

Keywords: Exercise; High-intensity interval training; Adolescent health.

\section{RESUMO}

Tem sido evidenciado que o exercício físico combinado éuma abordagem não farmacológica eficiente no âmbito da saúde pública, uma vez que tem demonstrado resultados satisfatórios na prevenção, tratamento e controle de diversas morbidades. Portanto, éessencial a sistematização do conhecimento atual para que profissionais envolvidos na prescrição de exercícios físicos possam fazê-lo baseados em evidências. Dessa forma, o objetivo do presente estudo foi realizar uma revisão sistemática de ensaios clínicos randomizados para verificar as alterações dos fatores de risco cardiometabólicos induzidas pelo treinamento intervalado de alta intensidade (HIIT) e treinamento resistido (TR) em adolescentes. A busca sistemática foi realizada nas seguintes bases de dados: Pubmed, ScienceDirect, Cochrane, LILACS e Scielo. Inicialmente foram identificados 933 estudos, em seguida, dois pesquisadores eliminaram as duplicações e os manuscritos que não atenderam aos critérios de elegibilidade. Assim, foram incluídos dois artigos que atenderam aos critérios de inclusão: ensaio clínico randomizado conduzido com adolescentes (10 a 19 anos) de ambos os sexos, intervenção com duração de, pelo menos, quatro semanas, que prescreveu HIIT e TR na mesma sessão ou não, e avaliação de, pelo menos, um fator de risco cardiometabólico. Os resultados demonstraram que oito a 12 semanas de HIIT e TR, sem intervenção nutricional, foram eficazes para reduzir significativamente a circunferência da cintura e o percentual de gordura. Entretanto, os dados pertinentes à eficácia dessa combinação sobre o risco de desenvolvimento de diabetes mellitus tipo 2 e hipertensão arterial são controversos. Diante do exposto, verifica-se, a partir dos estudos incluidos, que a combinação de HIIT e TR tem o potencial de reduzir fatores de risco cardiometabólicos em adolescentes, portanto, novos estudos devem ser realizados para determinar a efetividade dessa prescrição de exercícios físicos. Nível de Evidência ll; Revisão sistemática de Estudos de Nível Il ou Nível I com resultados discrepantes.

Descritores: Exercício; Treinamento intervalado de alta intensidade; Saúde do adolescente.

\section{RESUMEN}

Se ha evidenciado que el ejercicio físico combinado es un enfoque no farmacológico eficiente en el ámbito de la salud pública, ya que ha demostrado resultados satisfactorios en la prevención, tratamiento y control de diversas morbilidades. Por lo tanto, es esencial la sistematización del conocimiento actual, para que los profesionales involucrados en la prescripción de ejercicios físicos puedan hacerlo basándose en evidencias. De esta forma, el objetivo del presente estudio fue realizar una revisión sistemática de ensayos clínicos aleatorizados para verificar los cambios de los factores de riesgo cardiometabólicos inducidos por el entrenamiento en intervalos de alta intensidad (HIIT) y entrenamiento resistido (ER) en adolescentes. La búsqueda sistemática se realizó en las siguientes bases de datos: 
Pubmed, ScienceDirect, Cochrane, LILACSy Scielo. Inicialmente se identificaron 933 estudios, luego dos investigadores eliminaron las duplicaciones y los manuscritos que no cumplieron los criterios de elegibilidad. Así, se incluyeron dos artículos que cumplieron estos criterios de inclusión: ensayo clínico aleatorizado conducido con adolescentes (10 a 19 años) de ambos sexos, intervención con una duración de al menos cuatro semanas, que prescribió HIIT y ER en la misma sesión o no, y evaluación de al menos un factor de riesgo cardiometabólico. Los resultados demostraron que ocho a 12 semanas de HIIT y ER, sin intervención nutricional, fueron eficaces para reducir significativamente la circunferencia de la cintura y el porcentaje de grasa. Sin embargo, los datos pertinentes sobre la eficacia de esta combinación sobre el riesgo de desarrollar diabetes mellitus tipo 2 e hipertensión arterial son controvertidos. Delante de lo expuesto se verifica, a partir de los estudios incluidos, que la combinación de HIIT y ER tiene el potencial de reducir factores de riesgo cardiometabólicos en adolescentes, por lo tanto, deben ser realizados nuevos estudios para determinar la efectividad de esa prescripción de ejercicios físicos. Nivel de evidencia Il; Revisión sistemática de Estudios de Nivel II o Nivel I con resultados discrepantes.

Descriptores: Ejercicio; Entrenamiento de intervalos de alta intensidad; Salud del adolescente.

\section{INTRODUCTION}

The increasing prevalence of overweight and obesity has become one of the most serious health problems in the 21 st century. ${ }^{1}$ Studies indicate that increased body fat distribution is strongly associated with higher incidence of cardiometabolic risk factors, including insulin resistance, hypertension, and dyslipidemia. ${ }^{1,2}$

Evidence shows that physical exercise is a non-pharmacological intervention that is effective for reducing the risk of cardiometabolic risk factors. ${ }^{3,4}$ Traditionally, continuous aerobic exercise has been the most commonly prescribed owing to its already demonstrated benefits for cardiovascular health and weight control. ${ }^{4}$ Considering that lack of time is one of the main barriers to exercise among adolescents, ${ }^{5}$ in recent decades, researchers have demonstrated that high-intensity interval training (HIIT) is an efficient method for the development of performance and cardiometabolic health indicators in different populations, ${ }^{6,7}$ besides its lower exercise volume and session duration. Furthermore, the literature suggests that HIIT presents similar results ${ }^{8}$ or has an even greater effect ${ }^{9}$ on these indicators in relation to continuous training.

Another possible physical exercise that has been added to the current recommendations with the aim of both prevention and treatment of cardiometabolic risk factors in the pediatric population is resistance training (RT). 3,10 Furthermore, the benefits resulting from the practice of RT in this population can go beyond the improvement of the factors generally mentioned in the literature to include the development of bone health and improvement of self-esteem. ${ }^{11}$ Thus, to achieve greater benefits, the prescription of both types of training (aerobic and resistance), within the same micro-cycle but not necessarily in the same session, characterizing combined training, has been recommended. ${ }^{12,13}$

Researchers have discussed possible HIIT interference in the adaptations associated with RT. ${ }^{13.14}$ In this sense, Pugh et al. ${ }^{15}$ analyzed the acute effects of the combination of HIIT and RT on molecular responses in untrained men. The results showed no acute interference in the signaling of contractile proteins and mitochondrial biogenesis indicators, which suggests that this combination may favor the optimization of adaptation. However, in a recent randomized clinical trial, ${ }^{14}$ the effects on strength indicators and cardiometabolic risk factors associated with 8 weeks of RT only and combined HIIT and RT in premenopausal women were evaluated. The authors concluded that HIIT before RT did not cause any interference effects on strength gains or induce significant changes in body composition or blood pressure. Thus, these results suggest that the adjustments caused by the combination of HIIT and RT on cardiometabolic risk factors are not yet clear, especially in young people.
Therefore, it is essential to systematize current knowledge from randomized clinical trials so that professionals involved in prescribing physical exercise can do so based on scientific evidence. Along these lines, the goal of this study was to perform a systematic review of randomized clinical trials to verify the changes in cardiometabolic risk factors induced by HIIT and RT in adolescents.

\section{METHODS}

This research was a systematic review. For this study, the recommendations of the PRISMA protocol ${ }^{16}$ were followed, and the review was recorded in PROSPERO (CRD42018083542). The review included randomized clinical trials, published or accepted for publication, conducted in adolescents (10 to 19 years of age) of both sexes, with the intervention lasting at least 4 weeks, with or without HIIT and RT in the same session and an evaluation of at least one cardiometabolic risk factor. The exclusion criteria were as follows: food restriction only for the intervention group, inclusion of patients with physical or mental pathological conditions, and studies with duplication of information in other investigations, monographs, dissertations, and theses.

\section{Database and systematic search}

Systematic searches were conducted in the following databases: PubMed (1950 to December 2017), Science Direct (1997 to December 2017), Cochrane (1993 to December 2017), LILACS (Latin American and Caribbean Literature in Health Sciences; 1982 to December 2017), and Scielo (Online Scientific Electronic Library; 1997 to December 2017). The final survey was conducted on May 27, 2018, without the use of a filter for publication date and language.

The PICO method was used to structure the systematic search: P (population), adolescents; I (intervention), HIIT and TR; C (comparison), no intervention or control group; and $\mathrm{O}$ (outcome), cardiometabolic risk factors. Thus, the following descriptors were used in English, Spanish, and Portuguese, combined according to the Boolean algebra: (adolescent OR young OR teenager) AND (high-intensity interval training OR aerobic interval training OR resistance training OR strength training) AND (cardiometabolic health OR cardiometabolic risk factors OR metabolic syndrome).

\section{Selection of studies}

A systematic search of the databases was conducted independently by two researchers (WFF and FRM) who extracted the titles and abstracts. Then, the studies were selected by reading the titles and abstracts blindly (WFF and FRM). In the next step, the articles were read in full (WFF and FRM). The references of full-text articles evaluated for eligibility were manually analyzed to obtain more randomized clinical trials that were not identified by the electronic search. Any disagreement between the two researchers was referred to a third researcher (ASN). 


\section{Data extraction}

From the eligible studies, the following data were extracted: a) authors, b) characteristics of the subjects, c) characteristics of the intervention, d) outcome (measurement of cardiometabolic risk factors), e) main results, and f) conclusion. The same data extraction form was used by all the authors.

\section{Risk assessment of bias and methodological quality of studies}

To assess the risk of bias and methodological quality, each study was blindly evaluated by two researchers (WFF and FRM). When there was disagreement between the two researchers, a third researcher (ASN) was consulted. The risk of bias was assessed on the basis of the recommendations of the Cochrane Collaboration Handbook. The following aspects were evaluated: generation of the randomization sequence, allocation secrecy, blinding of participants and staff, blinding in the evaluation of outcomes, incomplete outcome data, selective reporting of outcomes, and other sources of bias.

To assess methodological quality, the PEDro scale was also used. ${ }^{17}$ This scale consists of 11 questions aimed at verifying the validity and sufficiency of the statistical information of the studies. The first question, which is related to external validity, was not scored. When each item met the required criteria, it received one point, making it possible to classify the quality of each study as follows: poor $(<4)$, moderate $(4$ or 5$)$, good $(6-8)$ and excellent (9 or 10). Studies with scores $\geq 6$ were considered of high quality.

\section{Definitions}

HIIT has been defined as repeated sequences of high-intensity effort followed by various recovery times. It can be performed on treadmills, cycle ergometers, or tracks, among others. ${ }^{13}$ Conversely, RT is a combination of static and dynamic contractions involving the contraction and distension of skeletal muscles against an external resistance. It can be performed with free weights (dumbbells and bars), body weight, elastic, springs, or machines, among others. ${ }^{18}$ Cardiometabolic risk factors are a set of risk factors of cardiovascular disease and type 2 diabetes mellitus. ${ }^{3}$ For this study, the following factors were considered: fat percentage; waist circumference; and levels of fasting glucose, fasting insulin, triglycerides, and total cholesterol; and resting blood pressure.

\section{RESULTS}

\section{Search results}

The systematic database search identified 933 studies (Figure 1). Initially, duplicate studies were excluded (87 studies), and then two researchers eliminated by title and/or abstract the references that were not in accordance with the inclusion criteria (808 studies). Subsequently, the references of the selected manuscripts were screened (38 studies); soon after, the articles were fully analyzed to verify if they met the eligibility criteria. Two eligible manuscripts provided data for qualitative analysis. ${ }^{19,20}$

The reasons for study exclusion are described in Table 1. These studies prescribed continuous training and RT (20 studies), sports activities only (2 studies), continuous training only (3 studies), other combinations of exercises (7 studies), and adult individuals as samples (4 studies).

\section{Sample characteristics and exercise details}

The characteristics of the studies included in the systematic review are described in Table 2. Logan et al. ${ }^{19}$ analyzed the effects of 8 weeks of HIIT and RT on cardiometabolic risk factors in 26 male adolescents. The participants were randomized into five groups (HIIT + RT 1, HIIT + RT 2, HIIT + RT 3, HIIT + RT 4, and HIIT + RT 5), with distinct volumes of HIIT.

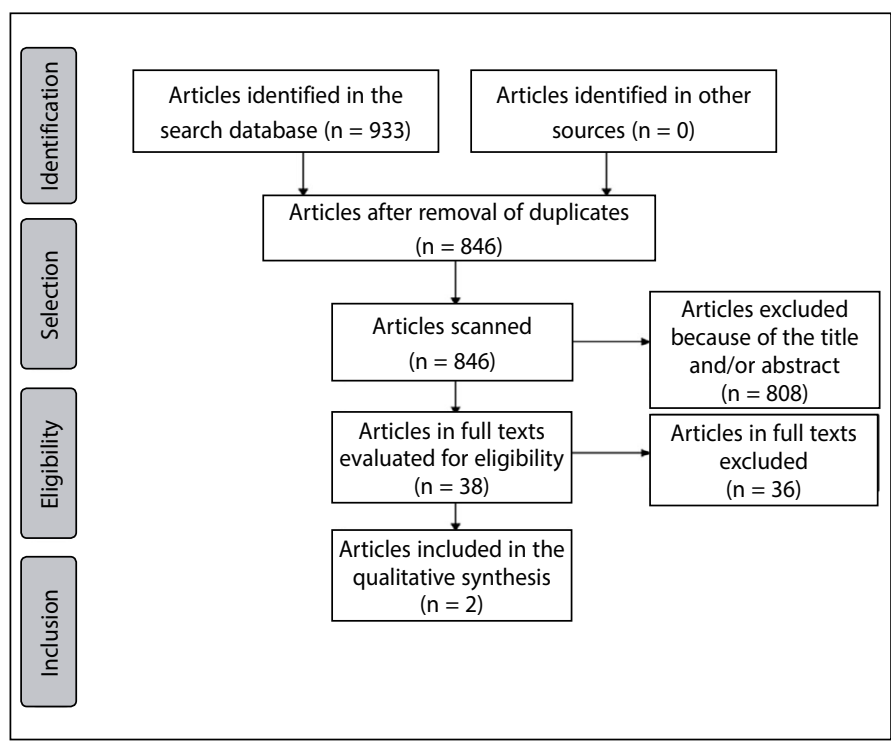

Figure 1. Flowchart of the strategic search.

Table 1. Characteristics of the excluded studies.

\begin{tabular}{|c|c|}
\hline Author & Reason for exclusion \\
\hline $\begin{array}{c}\text { Earnest et al. }(2014)^{21} \\
\text { Forsell et al. }(2015)^{22} \\
\text { Huffman et al. }(2014)^{23} \\
\text { Ormsbee et al. }(2015)^{24} \\
\end{array}$ & $\begin{array}{l}\text { The participants included in this systematic review } \\
\text { were adolescents. The studies in } \\
\text { this group analyzed adults. }\end{array}$ \\
\hline $\begin{array}{c}\text { Ackel-D'Elia et al. }(2014)^{25} \\
\text { Alberga et al. }(2012)^{26} \\
\text { Alberga et al. }(2015)^{27} \\
\text { Antunes et al. }(2013)^{28} \\
\text { Antunes et al. }(2015)^{29} \\
\text { Bell et al. }(2007)^{30} \\
\text { Browning et al. }(2015)^{31} \\
\end{array}$ & \multirow[b]{2}{*}{$\begin{array}{l}\text { The modalities of the physical exercises of interest } \\
\text { in this review were high-intensity interval training } \\
\text { (HIIT) and resistance training. The studies in this } \\
\text { group performed continuous aerobic exercise } \\
\text { in combination with resistance training. }\end{array}$} \\
\hline $\begin{array}{c}\text { Bruyndonckx et al. }(2015)^{32} \\
\text { Campos et al. (2014) } \\
\text { Dâmaso et al. }(2014)^{12} \\
\text { Davis et al. }(2011)^{34} \\
\text { Foschini et al. }(2010)^{35} \\
\text { Gow et al. }(2016)^{36} \\
\text { Inoue et al. }(2015)^{37} \\
\text { Mello et al. }(2011)^{38} \\
\text { Mendelson et al. }(2015)^{39} \\
\text { Monteiro et al. }(2015)^{40} \\
\text { Piano et al. }(2012)^{41} \\
\text { Sigal et al. }(2014)^{42} \\
\text { Son et al. }(2017)^{43} \\
\end{array}$ & \\
\hline $\begin{array}{l}\text { Calcaterra et al. }(2013)^{44} \\
\text { Reinehr et al. }(2011)^{45}\end{array}$ & \multirow[b]{2}{*}{$\begin{array}{c}\text { Prescription of sports activities only } \\
\text { Resistance training and sports activities } \\
\text { Continuous aerobic training only } \\
\text { Circuit-strength training only } \\
\text { HIIT and sports activities } \\
\text { Continuous aerobic training only } \\
\text { Continuous aerobic training only } \\
\text { Continuous aerobic training and sport activities } \\
\text { Walking and jogging training } \\
\text { Continuous aerobic training and exercises in Wii Fit } \\
\text { Combined training and sports activities }\end{array}$} \\
\hline $\begin{array}{c}\text { Carrel et al. }(2005)^{46} \\
\text { Fayh et al. }(2013)^{47} \\
\text { Giannaki et al. }(2016)^{48} \\
\text { Gueugnon et al. }(2012)^{49} \\
\text { Huang et al. }(2015)^{50} \\
\text { Kamal \& Ragy. }(2012)^{51} \\
\text { Kelishadi et al. }(2008)^{52} \\
\text { Knox et al. }(2012)^{53} \\
\text { Mccormack et al. }(2014)^{54} \\
\text { Vrablík et al. }(2014)^{55} \\
\end{array}$ & \\
\hline
\end{tabular}

In a college facility, HIIT was prescribed twice a week in blocks as follows: 4 sequences of $20 \mathrm{~s}\left(90-100 \%\left(\mathrm{CF}_{\max }\right)\right.$ interspersed with $10 \mathrm{~s}$ of passive recovery, with a total of 11 minutes per session on average. RT was performed once a week in all the groups in 3 sets, with 8 to 12 repetitions (70\% of $1 \mathrm{RM}$ ) of the exercises, including supine, seated rowing, leg press, dumbbells, and squats, for a total of approximately 30 minutes per session.

Racil et al..$^{20}$ verified the effects of 12 weeks of HIIT and RT with plyometric exercises on the metabolic health of 26 female adolescents with 
Table 2. Characteristics of the included studies.

\begin{tabular}{|c|c|c|c|c|c|}
\hline Author & Subjects & Intervention & Outcome & $\begin{array}{c}\text { Results (Mean } \\
\text { percentage [range]) }\end{array}$ & Conclusion \\
\hline $\begin{array}{l}\text { Logan et al. } \\
(2016)^{19}\end{array}$ & $\begin{array}{c}-\mathrm{n}=26 \text { non-active male } \\
\text { adolescents who did not } \\
\text { participate in structured } \\
\text { physical activities } \\
\text { (16.0 } 1.0 \text { years) } \\
\text { - They were randomized } \\
\text { into five groups (HIIT + } \\
\text { TR, HIIT + TR, HIIT + TR, } \\
\text { HIIT + TR, and HIIT + TR). } \\
\text { - HIIT + RT 1: } n=5 \\
\text { - HIIT + RT 2: } n=5 \\
\text { - HIIT + RT 3: } n=6 \\
\text { - HIIT + RT 4: } n=5 \\
\text { - HIIT + RT 5: } n=5\end{array}$ & 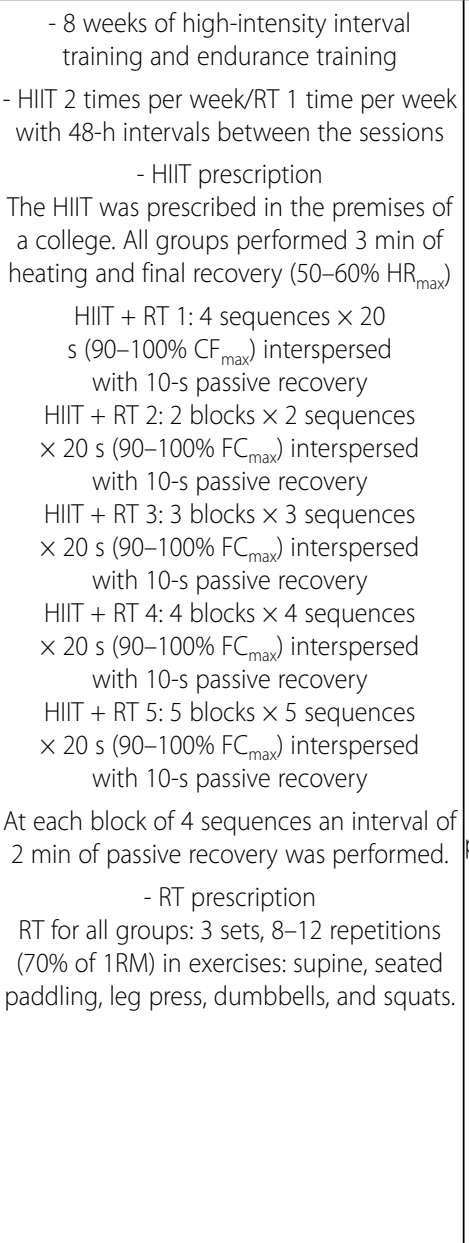 & $\begin{array}{c}\text { - Percentage of } \\
\text { fat estimated with } \\
\text { radiological densitometry } \\
\text { of double energy (DXA) } \\
\text { - Waist circumference: } \\
\text { in the erect position } \\
\text { at expiration, the } \\
\text { waist circumference } \\
\text { was measured with } \\
\text { a measuring tape at } \\
\text { the point of greatest } \\
\text { protuberance between } \\
\text { the iliac crest and the } \\
\text { last floating rib } \\
\text { - Glucose and insulin: } \\
\text { Blood was collected } \\
\text { after } 12 \text { hours of fasting. } \\
\text { Analysis of glucose and } \\
\text { insulin were performed } \\
\text { with specific tests } \\
\text { (Roche Modular E170) } \\
\text { - Blood pressure at rest: } \\
\text { after } 5 \text { minutes in the } \\
\text { sitting position, blood } \\
\text { pressure was checked with } \\
\text { an automatic monitor } \\
\end{array}$ & 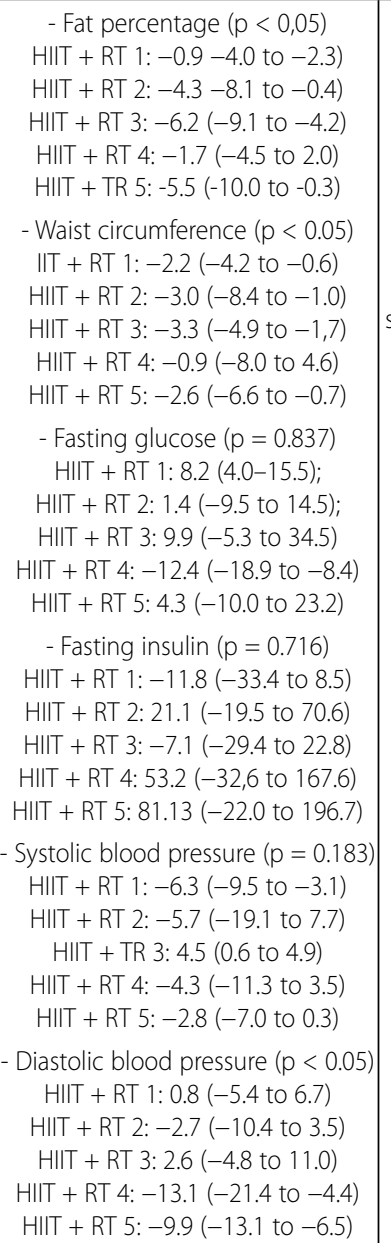 & $\begin{array}{l}\text { Eight weeks of HIIT } \\
\text { and weight training } \\
\text { induced significant } \\
\text { reductions in fat } \\
\text { percentage, waist } \\
\text { circumference, and } \\
\text { diastolic blood } \\
\text { pressure. Execution } \\
\text { of additional HIIT } \\
\text { sequences promoted } \\
\text { small improvements } \\
\text { in male adolescents } \\
\end{array}$ \\
\hline $\begin{array}{l}\text { Racil et al. } \\
(2016)^{20}\end{array}$ & $\begin{array}{c}-\mathrm{n}=68 \text { obese } \\
\text { female adolescents } \\
\text { (16.6 } \pm 1.3 \text { years) } \\
\text { - They were randomized } \\
\text { into three groups (HIIT } \\
+ \text { RT, HIIT, and control) } \\
\text { - HIIT + RT: } n=26 \\
\text { - HIIT: } n=23 \\
\text { - Control: } n=19\end{array}$ & $\begin{array}{l}-12 \text { weeks of high-intensity interval } \\
\text { training and endurance training on } \\
\text { the same day, } 3 \text { times per week with a } \\
48 \text {-hour interval between sessions. } \\
\text { - HIIT Prescription } \\
10 \text { min of heating and recovery } \\
\left(50 \% \mathrm{VO}_{2 \text { peak }} \text {. HIIT was prescribed }\right. \\
\text { on a } 200 \text {-m runway. } \\
2 \text { blocks } \times 6 \text { to } 8 \text { sequences } \times 30 \mathrm{~s} \\
\left(100 \% \mathrm{VO}_{2 \text { peak }} \text { ) interspersed with } 30\right. \\
\mathrm{s} \text { of active recovery (50\% } \mathrm{VO}_{2 \text { peak) }} \text {. } \\
\text { At each block from } 6 \text { to } 8 \\
\text { sequences, a } 4 \text {-min passive recovery } \\
\text { interval was performed. } \\
\quad-\mathrm{RT} \text { prescription } \\
\text { first to fourth week: } 2 \text { blocks } \times 4 \\
\text { sequences } \times 15 \mathrm{~s} \text { in exercises: jumping } \\
\text { with both legs, throwing the medicine } \\
\text { ball above the head, and diving in } \\
\text { the medicine ball with one leg } \\
\text { fifth to eighth week: } 2 \text { blocks } \times 4 \\
\text { sequences } \times 15 \mathrm{~s} \text { of exercises, including } \\
\text { jumps with obstacles, zigzag jumps, and } \\
\text { throwing a medicine ball on one's back. } \\
\text { ninth to } 12 \text { th week without: } 2 \text { blocks } \\
\times 4 \text { sequences } \times 15 \mathrm{~s} \text { of exercises, } \\
\text { including jumping over the cone with } \\
\text { one leg, zig-zag with one leg, and } \\
\text { throwing a medicine ball to a partner. } \\
\text { For each new block or fiscal year, an } \\
\text { interval of } 1.5 \text { min was executed. } \\
\text { Inspection: Lack of training. }\end{array}$ & $\begin{array}{c}\text { - Fat percentage: } \\
\text { estimated by } \\
\text { bioimpedance (TBF-300) } \\
\text { - Waist circumference: } \\
\text { in the erect position, } \\
\text { the waist circumference } \\
\text { was measured with } \\
\text { a measuring tape at } \\
\text { the point of greatest } \\
\text { protuberance between } \\
\text { the iliac crest and the } \\
\text { last floating rib. } \\
\text { - Fasting glucose: blood } \\
\text { was collected after } \\
12 \text { hours of fasting. } \\
\text { Blood glucose analysis } \\
\text { was performed using } \\
\text { an automatic device } \\
\text { (Architect c8000) } \\
\text { - Fasting insulin: blood } \\
\text { was collected after } \\
\text { a } 12 \text {-h fast. Insulin } \\
\text { analysis was performed } \\
\text { using the method (RIA) } \\
\text { (Immunotech A) }\end{array}$ & $\begin{array}{c}\text { - Fat percentage } \\
\text { HIIT + RT: }-7.2 \pm 1.8(p<0.05) \\
\text { Control: } 0.6 \pm 0.9 \\
\text { - Waist circumference } \\
\text { HIIT + RT: }-4.0 \pm 1.0(p<0.05) \\
\text { Control: }-0.6 \pm 0.6 \\
\text { - Fasting glucose level } \\
\text { HIIT + RT: }-11.0 \pm 4,7(p<0.05) \\
\text { Control: } 1.3 \pm 3.5 \\
\text { - Fasting insulin level } \\
\text { HIIT + RT: }-29.5 \pm 5.6(p<0,05) \\
\text { Control: }-3.2 \pm 3.2\end{array}$ & $\begin{array}{l}\text { Twelve weeks of } \\
\text { HIIT and resistance } \\
\text { training through } \\
\text { plyometric exercises } \\
\text { induced significant } \\
\text { reductions in the } \\
\text { percentage of fat, } \\
\text { waist circumference, } \\
\text { glucose and insulin } \\
\text { concentrations } \\
\text { in adolescents } \\
\text { with obesity }\end{array}$ \\
\hline
\end{tabular}


obesity. The exercise sessions were performed three times a week, with a 48-hour interval. On a 200-m track, HIIT was performed in two blocks of 6 to 8 sequences with a duration of $30 \mathrm{~s}\left(100 \% \mathrm{VO}_{2 \text { peak }}\right)$ interspersed with 30 s of active recovery $\left(50 \% \mathrm{VO}_{2 \text { peak }}\right)$. The RT was composed of plyometric exercises, including two blocks of 4 sequences executed by $15 \mathrm{~s}$ with 90-s intervals between the sequences. Every 4 weeks, the complexity of the exercises of the lower and upper limbs was increased. The total time of the HIIT and RT sessions were 40 and 10 min, respectively.

Regarding the comparison or control group, only the study by Racil et al. ${ }^{20}$ included a control group with 19 adolescents. This group was instructed to maintain the practice of usual physical activities and not to change dietary habits. Both studies provided specialized supervision in conducting the training sessions. As for participation in the sessions, the included studies reported a frequency of $\geq 85 \%$.

\section{Cardiometabolic risk factors}

\section{Fat percentage and waist circumference}

Male adolescents who completed an 8-week intervention, including HIIT and RT, had significant reductions in their fat percentages and waist circumferences. ${ }^{19}$ Similarly, in the adolescents with obesity, 12 weeks of HIIT and RT without nutritional intervention were sufficient to reduce fat percentage and waist circumference. ${ }^{20}$

\section{Glycemic and lipid profiles}

Significant reductions in fasting insulin and blood glucose concentrations induced by physical training were found in girls with obesity who participated in 12 weeks of plyometric and HIIT exercise. ${ }^{20}$ By contrast, the combination of resistance exercise with HIIT did not modify fasting insulin and blood glucose levels in inactive adolescents. ${ }^{19}$ The studies included in this review did not analyze the concentrations of triglycerides and total cholesterol.

\section{Resting blood pressure}

Only the study by Logan et al. ${ }^{19}$ evaluated resting systolic and diastolic blood pressures in response to HIIT and RT in adolescents. After 8 weeks of intervention, a significant decrease in diastolic blood pressure but no significant changes in systolic blood pressure were observed.

\section{Risk of bias and methodological quality}

The risk of bias is presented in Table 3. The studies included ${ }^{19.20}$ did not employ confidentiality in the allocation of participants, characterizing a high risk of bias in this domain. In addition, these studies did not provide sufficient information regarding the blinding of the participants, team, and outcome evaluation. The agreement between the researchers in the evaluation of risk of bias was considered good (Kappa $=0.76$ ).

Regarding the methodological quality of the studies, the studies by Logan et al. ${ }^{19}$ and Racil et al. ${ }^{20}$ reached 6 points on the PEDro scale because they did not report blinding of participants, professionals, and evaluators. Thus, it can be stated that the studies included presented good methodological quality. In relation to the agreement among the researchers, the Kappa index showed perfect agreement. Details on the methodological quality are described in Table 4.
Table 4. Methodological quality of the studies included in the systematic review, assessed on the PEDro scale.

\begin{tabular}{|c|c|c|}
\hline \multirow[b]{2}{*}{ Questions } & \multicolumn{2}{|c|}{ Author } \\
\hline & $\begin{array}{l}\text { Logan et al. } \\
\qquad(2016)\end{array}$ & $\begin{array}{l}\text { Racil et al. } \\
\text { (2016) }\end{array}$ \\
\hline 1. The eligibility criteria have been specified*. & Yes & Yes \\
\hline 2. The subjects were randomly distributed into groups. & Yes & Yes \\
\hline 3. The distribution of participants was blind. & No & No \\
\hline $\begin{array}{l}\text { 4. Initially, the groups were similar in terms of } \\
\text { the most important prognostic indicators. }\end{array}$ & Yes & Yes \\
\hline 5. All the subjects participated blindly in the study. & No & No \\
\hline $\begin{array}{l}\text { 6. All the professionals who administered } \\
\text { the intervention did so blindly. }\end{array}$ & No & No \\
\hline $\begin{array}{l}\text { 7. All evaluators who measured at least } \\
\text { one key outcome did so blindly. }\end{array}$ & No & No \\
\hline $\begin{array}{l}\text { 8. Measurements of at least one key outcome } \\
\text { were obtained from }>85 \% \text { of the subjects } \\
\text { initially assigned to the groups. }\end{array}$ & Yes & Yes \\
\hline $\begin{array}{l}\text { 9. All the subjects from whom measurements of } \\
\text { results were taken were either treated or controlled } \\
\text { according to distribution, or where this was not } \\
\text { the case, the data were analyzed for at least one } \\
\text { of the key results by "intended treatment." }\end{array}$ & Yes & Yes \\
\hline $\begin{array}{l}\text { 10. The results of intergroup statistical comparisons } \\
\text { have been described for at least one key outcome. }\end{array}$ & Yes & Yes \\
\hline $\begin{array}{l}\text { 11. The study presents both precision and variability } \\
\text { measures for at least one key outcome. }\end{array}$ & Yes & Yes \\
\hline Total score & 6 & 6 \\
\hline
\end{tabular}

*Question 1 does not contribute to the total score.

\section{DISCUSSION}

Physical exercise has been demonstrated to be an efficient non-pharmacological approach in public health, as it is important in the prevention, treatment, and control of various morbidities. ${ }^{4.11}$ However, the type and dose of exercise required to induce benefits to cardiometabolic health is still a controversial issue, especially in adolescents. ${ }^{3,4,11}$ On the basis of the results presented in the eligible articles in this review, the combination of HIIT and RT has the potential to reduce cardiometabolic risk factors in the pediatric population. However, only little convincing evidence has been found to support the efficacy of this combination for all outcomes.

The increased prevalence rates of overweight and obesity in childhood and adolescence are considered a public health problem of concern because these morbidities have been associated with health risks. ${ }^{1}$ In adolescents of both sexes, 8 to 12 weeks of HIIT and RT without nutritional intervention were effective in significantly reducing waist circumference and fat percentage. ${ }^{19,20}$

When we analyzed the isolated effects of each of these training methods, we observed in the literature that HIIT has been shown to be efficient in reducing the percentage of fat in the pediatric population. $6,7,56$ Likewise, RT promotes a reduction in the percentage of fat, but at a lower magnitude than HIIT does. ${ }^{10.13}$ In this sense, the combination of these training methods for 8 to 12 weeks induced a significant loss of body fat, including an increase in lean mass, ${ }^{19.20}$ characterizing a greater number of

Table 3. Risk of bias of the studies included in the systematic review.

\begin{tabular}{|c|c|c|c|c|c|c|c|}
\hline & \multicolumn{7}{|c|}{ Risk of bias } \\
\hline Author & Randomization & $\begin{array}{c}\text { Allocation } \\
\text { secrecy }\end{array}$ & $\begin{array}{c}\text { Blinding of participants } \\
\text { and team }\end{array}$ & $\begin{array}{c}\text { Blinding in the } \\
\text { evaluation of outcomes }\end{array}$ & $\begin{array}{c}\text { Incomplete } \\
\text { outcome data }\end{array}$ & $\begin{array}{c}\text { Selective reporting } \\
\text { of outcomes }\end{array}$ & $\begin{array}{c}\text { Other sources } \\
\text { of biases }\end{array}$ \\
\hline Logan et al. (2016) & Low & High & High & Uncertain & Low & Low & Low \\
\hline Racil et al. (2016) & Low & High & High & Uncertain & Low & Low & Low \\
\hline
\end{tabular}


important adaptations than with only one type of exercise. These results can be explained by negative energy balance, increased mitochondrial biogenesis, and neural and structural adaptations of the skeletal muscle. 15,57

High fasting glucose and insulin concentrations can be considered warning signs for the development of diabetes mellitus type 2 and other related metabolic changes. ${ }^{58}$ Available data from systematic reviews and randomized clinical trials showed that $H \| T^{6,7,49,56}$ and $R T^{10,46,48}$ performed alone have the potential to reduce the risk of diabetes mellitus type 2 in the pediatric population.

Considering the studies included in this review, the combination of HIIT and RT promoted significant reductions in plasma concentrations of fasting glucose and insulin levels in female adolescents with obesity, but no changes in these concentrations were found in male adolescents.

Although both studies adopted similar procedures in the analysis of fasting glucose and insulin levels, the sample size and specific characteristics of the volunteers, such as sex, nutritional status, and glucose profile, may have contributed to the discrepant results. Thus, the absence of responses in glycemic metabolism in the study conducted with male adolescents can be explained by the small sample size of each group and by the normal levels of fasting glucose and insulin at baseline. ${ }^{57}$ In this context, the efficacy of the combination of HIIT and RT for the development of morbidities related to glycemic metabolism is not yet clear.

High blood pressure is considered the most important risk factor of cardiovascular disease, contributing to half of all cases of heart disease and about two thirds of all cases of cerebrovascular disease. ${ }^{59}$ The literature has shown that HIIT promotes a considerable hypotensive effect in hypertensive adolescents with high BP. 6,7 However, data on the efficacy of RT for altered blood pressure in this population are limited. ${ }^{10,48}$

With regard to the studies included in this review, only one analyzed resting systolic and diastolic blood pressures, which were measured with an automatic device. ${ }^{19}$ The results were a significant decrease in diastolic blood pressure, and a low-magnitude reduction in systolic blood pressure ( $p>0.05$ ) after 8 weeks of HIIT and RT in male adolescents.

The available evidence in the literature suggests that the hypotensive effect of physical exercise is greater in hypertensive individuals than in normotensive individuals $s^{60}$; thus, the low-magnitude reduction in blood pressure induced by the combined exercise intervention is relevant because it potentially promoted better regulation of blood pressure in the volunteers due to neurohumoral, vascular, and structural adjustments of the cardiac muscle. ${ }^{60}$ It is important to highlight that these data are limited, in view of the fact that they come from only one study, which highlights the need for further research on this topic.

In analyzing systematic reviews and randomized clinical trials that examined the effects of combined training (continuous aerobic and resistance) on cardiometabolic risk factors in adolescents, we observed that this type of training promoted improvement in body composition, metabolic profile and inflammatory status. ${ }^{12,34,36,43,57}$ The results of this review present promising evidence; however, they were based on only two studies, limiting the comparability of the results, as this investigation could not perform a more robust analysis of the data. Therefore, the evidence on the type and dose of combined exercise required to promote cardiometabolic health benefits is not fully understood at this time.

The studies included in this systematic review presented a considerable risk of bias due to the insufficient description of blinding in the evaluation of outcomes and allocation of participants. Although the investigations analyzed reached 6 points on the PEDro scale, the sample size was small in both studies, and the a priori calculation of the sample size was not performed. It should be pointed out that all studies were classified as having a high risk of bias in the domain "blinding of participants and team." Considering that it is practically impossible to "blind" participants in interventions with physical exercises, the risk of bias and methodological quality may have been underestimated.

Regarding the limitations of this investigation, the systematic search was performed only in journals indexed in the electronic databases PubMed, Science Direct, Cochrane, LILACS, and Scielo. Therefore, it is possible that some manuscripts on this topic have not been found. However, the databases used in this review are the most consulted for bibliographical research on manuscripts in Portuguese, English, and Spanish. In addition, a complete search was conducted in the references of the 38 articles evaluated for eligibility to find more studies. The investigation was conducted using only descriptors in Portuguese, English, and Spanish; therefore, existing studies in other languages were not included.

\section{CONCLUSION}

\section{Implications for practice}

Considering the results demonstrated by the articles included in this review, the combination of HIIT and RT has the potential to reduce cardiometabolic risk factors in adolescents. Relevant aspects of the combined exercise program refer to exercise tolerance in adolescents with eutrophy and obesity, participation in $>85 \%$ of the physical training sessions, easy application given that the interventions can be performed in school facilities, and relatively shorter total session time than those in traditional combined programs. However, HIIT and RT could not be recommended because of the small number of available studies on the subject.

\section{Implications for future research}

The influences of sex, nutritional status, ethnicity, and biological maturation on cardiometabolic health is not fully understood. ${ }^{3,4,11}$ Therefore, the discrepancies in cardiometabolic responses induced by HIIT and RT in adolescents may be due to the physiological characteristics of the population and/or limitations of the study design of the available investigations that met the inclusion criteria. Given that currently, no strong evidence has been found to determine the effectiveness of the combination of HIIT and RT on cardiometabolic risk factors, we recommend that further investigations be conducted with adolescents, following the guidelines of the Consort Statement.

From this perspective, the standardization of the measurement of cardiometabolic risk factors is necessary to minimize confounding factors such as choice of outcomes, instruments, and procedures of analysis. In addition, the manipulation of exercise prescription components (intensity, duration, frequency, and type) should be detailed and be in accordance with the guidelines of the American College of Sports Medicine $e^{4.18}$. This will facilitate comparability between studies and the development of future programs for prevention, treatment, and control of cardiometabolic risk factors.

$\overline{\text { All authors declare no potential conflict of interest related to this article }}$

AUTHORS' CONTRIBUTIONS: Each author made significant individual contributions to this manuscript. WFF (0000-0003-3407-6372): participated in the initial conception of the study, systematic search, writing and critical review of the text; FRM (0000-0001-9940-7617): systematic search, writing and critical review of the text; RGME (0000-0002-0040-8212): writing and critical review of the text; RGO (0000-0003-0904-9305): participated in the initial conception of the study and critical review of the text; ASN (0000-0003-2931-943X): participated in the initial conception of the study, writing and critical review of the text. ${ }^{*} \mathrm{ORCID}$ (Open Researcher and Contributor ID). 


\section{REFERÊNCIAS}

1. Ng M, Fleming T, Robinson M, Thomson B, Graetz N, Margono C, et al. Global, regional and national prevalence of overweight and obesity in children and adults 1980-2013: a systematic analysis. Lancet. 2014;384(9945):766-81.

2. Skinner AC, Perrin EM, Moss LA, Skelton JA. Cardiometabolic risks and severity of obesity in children and young adults. N Engl J Med. 2015;373(14):1307-17.

3. Expert Panel on Integrated Guidelines for Cardiovascular Health and Risk Reduction in Children and Adolescents. Expert panel on integrated guidelines for cardiovascular health and risk reduction in children and adolescents: summary report. Pediatrics. 2011;128(suppl 5):S213-56.

4. Garber CE, Blissmer B, Deschenes MR, Franklin BA, Lamonte MJ, Lee IM, et al. Quantity and quality of exercise for developing and maintaining cardiorespiratory, musculoskeletal, and neuromotor fitness in apparently healthy adults: guidance for prescribing exercise. Med Sci Sports Exerc. 2011;43(7):1334-59.

5. Dias DF, Loch MR, Ronque ERV. Perceived barriers to leisure-time physical activity and associated factors in adolescents. Cien Saude Colet. 2015;20(11):3339-50.

6. Costigan SA, Eather N, Plotnikoff RC, Taaffe DR, Lubans DR. High-intensity interval training for improving health-related fitness in adolescents: a systematic review and meta-analysis. Br J Sports Med. 2015;49(19):1253-9.

7. Eddolls WTB, McNarry MA, Stratton G, Winn CON, Mackintosh KA. High-intensity interval training interventions in children and adolescents: a systematic review. Sport Med. 2017;47(11):2363-74.

8. Martins C, Kazakova I, Ludviksen M, Mehus I, Wisløff U, Kulseng B, et al. High-intensity interval training and isocaloric moderate-intensity continuous training result in similar improvements in body composition and fitness in obese individuals. Int J Sport Nutr Exerc Metab. 2016;26(3):197-204.

9. Weston M, Taylor KL, Batterham AM, Hopkins WG. Effects of low-volume high-intensity interval training (HIT) on fitness in adults: A meta-analysis of controlled and non-controlled trials. Sport Med. 2014:44(7):1005-17.

10. Faigenbaum AD, Kraemer WJ, Blimkie CJR, Jeffreys I, Micheli $\sqcup$, Nitka M, et al. Youth resistance training: Updated position statement paper from the national strength and conditioning association. J Strength Cond Res. 2009;23(5):60-79.

11. World Health Organization. Global recommendations on physical activity for health. 2010

12. Dâmaso AR, Campos RMS, Caranti DA, Piano A, Fisberg M, Foschini D, et al. Aerobic plus resistance training was more effective in improving the visceral adiposity, metabolic profile and inflammatory markers than aerobic training in obese adolescents. J Sport Sci. 2014;32(15):1435-45.

13. Silva RF, Cadore EL, Kothe G, Guedes M, Alberton CL, Pinto SS, et al. Concurrent training with different aerobic exercises. Int J Sports Med. 2012;33(8):627-34.

14. Gentil P, Lira CAB, Filho SGC, Teixeira CVLS, Steele J, Fisher J, et al. High intensity interval training does not impair strength gains in response to resistance training in premenopausal women. Eur $J$ Appl Physiol. 2017;117(6):1257-65.

15. Pugh JK, Faulkner SH, Jackson AP, King JA, Nimmo MA. Acute molecular responses to concurrent resistance and high-intensity interval exercise in untrained skeletal muscle. Physiol Rep. 2015;3(4):e12364.

16. Hutton B, Salanti G, Caldwell DM, Chaimani A, Schmid CH, Cameron C, et al. The PRISMA extension statement for reporting of systematic reviews incorporating network meta-analyses of health care interventions: checklist and explanations. Ann Intern Med. 2015;162(11):777-84.

17. Maher CG, Moseley AM, Sherrington C, Elkins MR, Herbert RD. A description of the trials, reviews, and practice guidelines indexed in the PDRro database. Phys Ther. 2008;88(9):1068-77.

18. Ratamess NA, Alvar BA, Evetoch TK, Housh TJ, Kibler WB, KraemerW, et al. Progression models in resistance training for healthy adults. Med Sci Sports Exerc. 2009;41(3):687-708.

19. Logan GRM, Harris N, Duncan S, Plank LD, Merien F, Schofield G. Low-active male adolescents: a dose response to high-intensity interval training. Med Sci Sports Exerc. 2016;48(3):481-90.

20. Racil G, Zouhal H, Elmontassar W, Ben A, Sousa MV, Chamari K, et al. Plyometric exercise combined with high-intensity interval training improves metabolic abnormalities in young obese females more so than interval training alone. Appl Physiol Nutr Metab. 2016;41(1):303-9.

21. Earnest $C P$, Johannsen NM, Swift DL, Gillison FB, Mikus CR, Lucia A, et al. Aerobic and strength training in concomitant metabolic syndrome and type 2 diabetes. Med Sci Sports Exerc. 2014;46(7):1293-301.

22. Forsell Y, Hallgren M, Mattson M, Ekblom O, Lavebratt C. FitForLife: study protocol for a randomized controlled trial. Trials. 2015;16(553):1-6.

23. Huffman KM, Koves TR, Hubal MJ, Abouassi H, Beri N, Bateman LA, et al. Metabolite signatures of exercise training in human skeletal muscle relate to mitochondrial remodelling and cardiometabolic fitness. Diabetologia. 2014;57(11):2282-95.

24. Ormsbee MJ, Kinsey AW, Eddy WR, Madzima TA, Arciero PJ, Figueroa A, et al. The influence of nighttime feeding of carbohydrate or protein combined with exercise training on appetite and cardiometabolic risk in young obese women. Appl Physiol Nutr Metab. 2015;4(1):1-9.

25. Ackel-D'Elia C, Carnier J, Bueno Jr CR, Campos RMS, Sanches PL, Clemente APG, et al. Effects of different physical exercises on leptin concentration in obese adolescents. Int J Sports Med. 2014;35(2):164-71.

26. Alberga AS, Goldfield GS, Kenny GP, Hadjiyannakis S, Phillips P, Prud'homme D, et al. Healthy eating, aerobic and resistance training in youth (HEARTY): study rationale, design and methods. Contemp Clin Trials. 2012;33(4):839-47.

27. Alberga AS, Prud'homme D, Kenny GP, Goldfield GS, Hadjiyannakis S, Gougeon R, et al. Effects of aerobic and resistance training on abdominal fat, apolipoproteins and high-sensitivity C-reactive protein in adolescents with obesity: the HEARTY randomized clinical trial. Int J Obes. 2015;39(10):1494-500.

28. Antunes BMM, Monteiro PA, Silveira LS, Cayres SU, Silva CM, Júnior IFF. Effect of concurrent training on risk factors and hepatic steatosis in obese adolescents. Rev Paul Pediatr. 2013;31(3):371-6.

29. Antunes BMM, Christofaro DGD, Monteiro PA, Silveira LS, Fernandes RA, Jorge M, et al. Effect of concurrent training on gender-specific biochemical variables and adiposity in obese adolescent. Arq Bras Endocrinol Metabol. 2015;59(4):303-9.

30. Bell LM, Watts K, Siafarikas A, Thompson A, Ratnam N, Bulsara M, et al. Exercise alone reduces insulin resistance in obese children independently of changes in body composition. J Clin Endocrinol Metab. 2007;92(11):4230-5.

31. Browning MG, Bean MK, Wickham EP, Stern M, Evans RK. Cardiometabolic and fitness improvements in obese girls who either gained or lost weight during treatment. J Pediatr. 2015;166(66):1364-9.
32. Bruyndonckx L, Hoymans VY, Guchtenaere A, Helvoirt MV, Craenenbroeck EMV, Frederix G, et al. Diet, exercise, and endothelial function in obese adolescents. Pediatrics. 2015;135(3):e653-61.

33. Campos RMS, Mello MT, Tock L, Silva PL, Masquio DL, Piano A, et al. Aerobic plus resistance training improves bone metabolism and inflammation in adolescents who are obese. J Strength Cond Res. 2014;28(33):758-66.

34. Davis JN, Gyllenhammer LE, Vanni AA, Meija M, Tung A, Schroeder ET, et al. Startup circuit training program reduces metabolic risk in latino adolescents. Med Sci Sports Exerc. 2011;43(11):2195-203.

35. Foschini D, Araújo RC, Bacurau RFP, Piano A, Almeida SS, Carnier J, et al. Treatment of obese adolescents: the influence of periodization models and ace genotype. Obesity. 2010;18(4):766-72.

36. Gow ML, Doorn NV, Broderick CR, Hardy LL, Ho M, Baur LA, et al. Sustained improvements in fitness and exercise tolerance in obese adolescents after a 12 week exercise intervention. Obes Res Clin Pract. 2016;10(2):178-88

37. Inoue DS, Mello MT, Foschini D, Lira FS, Ganen AP, Campos RMS, et al. Linear and undulating periodized strength plus aerobic training promote similar benefits and lead to improvement of insulin resistance on obese adolescents. J Diabetes Complications. 2015;29(2):258-64.

38. Mello MT, Piano A, Carnier J, Sanches PL, Corrêa FA, Tock L, et al. Long-term effects of aerobic plus resistance training on the metabolic syndrome and adiponectinemia in obese adolescents. J Clin Hypertens. 2011;13(5):343-50.

39. Mendelson M, Michallet AS, Monneret D, Perrin C, Estève F, Lombard PR, et al. Impact of exercise training without caloric restriction on inflammation, insulin resistance and visceral fat mass in obese adolescents. Pediatr Obes. 2015;10(4):311-9.

40. Monteiro PA, Chen KY, Lira FS, Thamyres B, Saraiva C, Moura B, et al. Concurrent and aerobic exercise training promote similar benefits in body composition and metabolic profiles in obese adolescents. Lipids Health Dis. 2015;14(153):1-9.

41. Piano A, Mello MT, Sanches PL, Silva PL, Campos RMS, Carnier J, et al. Long-term effects of aerobic plus resistance training on the adipokines and neuropeptides in nonalcoholic fatty liver disease obese adolescents. Eur J Gastroenterol Hepatol. 2012;24(11):1313-24.

42. Sigal RJ, Alberga AS, Goldfield GS, Prud'homme D, Hadjiyannakis S, Gougeon R, et al. Effects of aerobic training, resistance training, or both on percentage body fat and cardiometabolic risk markers in obese adolescents: the healthy eating aerobic and resistance training in youth randomized clinical trial. JAMA Pediatr. 2014;168(11):1006-14.

43. Son W, Sung K, Bharath LP, Choi K, Park SY. Combined exercise training reduces blood pressure, arterial stiffness, and insulin resistance in obese prehypertensive adolescent girls. Clin Exp Hypertens. 2017;39(6):546-52.

44. Calcaterra V, Larizza D, Codrons E, Silvestri A, Brambilla P, Abela S, et al. Improved metabolic and cardiorespiratory fitness during a recreational training program in obese children. J Pediatr Endocrino Metab. 2013;26(3-4):271-6.

45. Reinehr T, Schaefer A, Winkel K, Finne E, Kolip P. Development and evaluation of the lifestyle intervention "Obeldicks light" for overweight children and adolescents. J Public Health. 2011;19(4):377-84.

46. Carrel A, Meinen A, Garry C, Storandt R. Effects of nutrition education and exercise in obese children: the ho-chunk youth fitness program. Wis Med J. 2005;104(5):44-8.

47. Fayh APT, Lopes AL, Silva AMV, Reischak-Oliveira A, Friedman R. Effects of $5 \%$ weight loss through diet or diet plus exercise on cardiovascular parameters of obese: a randomized clinical trial. Eur J Nutr. 2013;52(5):1443-50.

48. Giannaki CD, Aphamis G, Tsouloupas CN, loannou Y, Hadjicharalambous M. An eight week schoolbased intervention with circuit training improves physical fitness and reduces body fat in male adolescents. J Sports Med Phys Fitness. 2016;56(7-8):894-900.

49. Gueugnon C, Mougin F, Nguyen NU, Bouhaddi M, Nicolet-Guénat M, Dumoulin G. Ghrelin and PYY levels in adolescents with severe obesity: effects of weight loss induced by long-term exercise training and modified food habits. Eur J Appl Physiol. 2012;112(5):1797-805.

50. Huang C, Kwok PC, Chou PC, Chou Y, Ho LT, Shih KC. The effect of exercise on lipid profiles and inflammatory markers in lean male adolescents: a prospective interventional study effects of exercise on body composition. J Investig Med. 2015;63(1):29-34.

51. Kelishadi R, Hashemipour M, Mohammadifard N, Alikhassy H, Adeli K. Short- and long-term relationships of serum ghrelin with changes in body composition and the metabolic syndrome in prepubescent obese children following two different weight loss programmes. Clin Endocrinol (Oxf). 2008;69(5):721-9.

52. Kamal NN, Ragy MM. The effects of exercise on C-reactive protein, insulin, leptin and some cardiometabolic risk factors in Egyptian children with or without metabolic syndrome. Diabetol Metab Syndr. 2012;4(1):1-7.

53. Knox G, Baker JS, Davies B, Faulkner S, Rance J, Rees A, et al. Effects of a novel school-based cross-curricular physical activity intervention on cardiovascular disease risk factors in 11- to 14-year-olds: the activity knowledge circuit. Am J Heal Promot. 2012;27(2):75-83.

54. McCormack SE, McCarthy MA, Harrington SG, Farilla L, Hrovat MI, Systrom DM, et al. Effects of exercise and lifestyle modification on fitness, insulin resistance, skeletal muscle oxidative phosphorylation and intramyocellular lipid content in obese children and adolescents. Pediatr Obes. 2014;9(4):281-91.

55. Vrablík M, Dobiášová M, Zlatohlávek L, Urbanová Z, Ceška RČ. Biomarkers of cardiometabolic risk in obese/overweight children: effect of lifestyle intervention. Physiol Res. 2014;63(6):743-52.

56. Wisløff U, Coombes JS, Rognmo O. CrossTalk proposal: High intensity interval training does have a role in risk reduction or treatment of disease. J Physiol. 2015;593(24):5215-7.

57. García-Hermoso A, Ramírez-Vélez R, Ramírez-Campillo R, Peterson MD, Martínez-Vizcaíno V. Concurrent aerobic plus resistance exercise versus aerobic exercise alone to improve health outcomes in paediatric obesity: a systematic review and meta-analysis. Br J Sports Med. 2018;52(3):161-6.

58. Stumvoll M, Goldstein BJ, van Haeften TW. Type 2 diabetes: principles of pathogenesis and therapy. Lancet. 2005;365(9467):1333-46.

59. Whitworth JA. 2003 World Health Organization (WHO)/International Society of Hypertension (ISH) statement on management of hypertension. J Hypertens. 2003;21(11):1983-92.

60. Pescatello LS, Franklin BA, Fagard R, Farquhar WB, Kelley GA, Ray CA. Exercise and Hypertension. Med Sci Sports Exerc. 2004:36(3):533-53. 